\title{
Skandinavisk translationsforskning ad nye veje: Om de-kontekstualisering af organisatorisk praksis
}

\author{
Af Jeppe Agger Nielsen *)
}

\section{Resumé}

Skandinavisk translationsforskning har navnlig fokuseret på, hvordan "idéer på rejse" tilpasses og modificeres i takt med, at de indoptages og implementeres $i$ organisationer (kontekstualisering). Til gengæld har få translationsstudier undersøgt, hvordan idéer løsrives fra organisationskontekster, så de kan udbredes i et felt (de-kontekstualisering). Denne artikel adresserer sidstnævnte problemstilling og viser gennem et longitudinelt case studie, hvordan en organisationspraksis, mindset-baseret undervisning, (som var inspireret af en global idé) blev udviklet og genfortolket på et dansk gymnasium, og båret frem af ildsjæle, der skabte forandring ikke alene i egen organisation, men også i feltet af danske undervisningsinstitutioner. Artiklen demonstrerer, hvordan "udbringning" af en organisatorisk praksis kræver omfattede translationsarbejde og ildsjæle, som kan skabe en vision, som rækker ud over egen organisation, opbygge alliancer og netværk i feltet samt formidle idéer i et kommunikerbart budskab.

*) Jeppe Agger Nielsen er ph.d. og professor (mso) ved Institut for Statskundskab på Aalborg Universitet. 


\section{A. Indledning}

Skandinavisk translationsforskning har etableret sig som et anerkendt forskningsfelt

(Czarniawska \& Joerges, 1996; Czarniawska \& Sevón, 2005; Boxenbaum \& Pedersen 2009; Røvik 2016), fremhævet som et af de fremadbrusende organisationsteoretiske perspektiver (Greenwood, Oliver, Sahlin-Andersson \& Suddaby 2008). Perspektivet benyttes til at belyse hvordan og hvorfor (moderigtige) organisationsidéer som fx Total Quality Management, Social Corporative Responsibility og Lean Management cirkulerer på tværs af landegrænser og felter, og hvordan de indoptages og implementeres i enkeltorganisationer (Sahlin-Andersson 1996; Morris \& Lancaster 2005; Sahlin \& Wedlin 2017).

Translationsforskningen har primært koncentreret sig om idéernes modtagerside, navnlig organisationsniveauet, og hvordan "idéer på rejse” tilpasses organisatoriske normer, værdier og behov i takt med at de indoptages $i$ organisationer (kontekstualisering) (Boxenbaum \& Pedersen 2009). Til gengæld har der, som vist i nyere litteraturstudier (Røvik 2016; Wæraas \& Nielsen 2016), været langt mindre bevågenhed om, hvordan organisationsidéer oversættes fra praksiskontekster og transformeres til mere eller mindre abstrakte koncepter, der kan udbredes i et felt (de-kontekstualisering). I nærværende artikel adresseres denne skævvridning i translationslitteraturen gennem et studie af de-kontekstualisering, nærmere bestemt det aspekt som Røvik (2007) betegner "udbringning” af organisationsidéer.

I dansk kontekst findes en række eksempler på organisationer og ledere, som med stor iver og virketrang formidler og promoverer praksisser uden for egen organisation, og derigennem tager aktiv del i udbringningen af idéer fra en specifik organisationskontekst. Det gælder fx tv-kokken Claus Meyers arbejde med tilblivelsen af”Ny Nordiske Køkken” (Nickelsen \& Scheuer 2009), "Fredericia modellen” for hverdagsrehabilitering (Kjellberg, Ibsen, Kjellberg 2011), Thyra Franks ledelsespraksis på plejehjemmet "Lotte” (Stokholm \& Lindholm 2013) og Viborg Gymnasium og HF's model for "mindset-baseret undervisning” (Kortnum, Nielsen \& Videsen 2016). Sidstnævnte anvendes som case i denne artikel, men fælles for ovennævnte organisationer og aktører er, at de alle har spillet en særdeles aktiv rolle i at få en lokal praksis til at "rejse”, og derigennem skabe et 
potentiale for forandring ikke alene i egen organisation, men også i det bredere organisatoriske felt ${ }^{1}$, som omslutter dem.

Denne artikel bidrager til skandinavisk translationsforskning med en undersøgelse af, hvordan dekontekstualiseringsprocesser forløber, hvilket hidtil har fået begrænset opmærksomhed i litteraturen. I artiklen zoomes-ind på det translationsarbejde, det kræver at "løsrive” en praksis fra en given organisatorisk kontekst, og omforme den til en abstrakt idé, der kan cirkulere i et felt eller en sektor. Til det formål bygger artiklen på et longitudinelt case studie af, hvordan en ny organisationspraksis, mindset-baseret undervisning, blev udviklet på Viborg Gymnasium og HF's (fremover VG), båret frem af ildsjæle, og søgt udbredt i feltet af danske undervisningsinstitutioner. Casen er ikke fortællingen om, hvorledes magtfulde feltaktører som ledelsesguruer, konsulenter, interesseorganisationer og forskningsinstitutioner promoverer og spreder nye idéer i et felt. Det er velbeskrevet i litteraturen (fx Abrahamson, 1996; SahlinAndersson \& Engwall, 2002). Til gengæld illustrerer casen, hvordan en lokal praksis (inspireret af en global idé) i en løbende og vekselvirkende proces kontekstualiseres og de-kontekstualiseres og vinder indpas i takt med, at en mere almindelig organisation søger at skabe forandring, ikke alene internt i egen organisation, men også i det felt, som de er en del af. Casen viser, hvordan "udbringning" af en organisatorisk praksis kræver entreprenant adfærd og omfattende translationsarbejde i og uden for egen organisation, men også at der kan opstå spændinger og dilemmaer, når en organisation agerer på to arenaer (organisation og felt) samtidigt.

I næste afsnit præsenteres artiklens teoretiske udgangspunkt, hvorefter der redegøres for casevalg og de anvendte metoder i artiklen. Dernæst følger analysen, og i det afsluttende afsnit sammenfattes artiklens hovedbudskaber, og artiklens forskningsbidrag udfoldes.

\section{B. Translation: Kontekstualisering og de-kontekstualisering}

Translation udgør et centralt teoretisk begreb i skandinavisk institutionel teori (Wæraas \& Nielsen, 2016). Som supplement til neo-institutionelle teorier, der forudser de-kobling (Meyer \&

\footnotetext{
${ }^{1}$ Et organisatorisk felt består af de aktører, der er involveret i frembringelsen, reguleringen og anvendelsen af et bestemt produkt eller en særlig ydelse. Det drejer sig eksempelvis om producenter, deres konkurrenter, leverandører, organisationer der regulerer området, brugere eller kunder (DiMaggio \& Powell 1983:143). Eksempler på organisatoriske felter i en offentlig kontekst er sygehusområdet, folkeskoleområdet eller som i dette studie uddannelsesområdet.
} 
Rowan, 1977) og isomorfisme (DiMaggio \& Powell, 1983) og diffusionsteorier, der anskuer innovationer, som relativt vanskelig omformelig i et spredningsforløb (Rogers, 1962)2, er translationslitteraturen særligt optaget af, hvordan organisationsidéer forandres i takt med, at de cirkulerer fra én kontekst til en anden. Udgangspunktet er derfor, at idéer bliver modificeret og tilpasset lokale kontekster, med det formål at øge deres egnethed i løsningen af konkrete opgaver (Czarniawska \& Sevón 1996; Pedersen \& Dobbin 1997). Translation knytter sig til transformation: "to set something in a new place or another point in time is to construct it anew" (Czarniawska 2009:425, se også Latour, 1986). Når en idé indoptages i en ny kontekst, knyttes der på ny rum, tid og skala til den (Sahlin-Andersson 1996) - den lokaliseres og tidsmarkeres (Røvik 2007). Translationslitteraturen er således optaget af, hvordan organisationsidéer forandres, i takt med at de indoptages i organisationer, hvor forskellige translationsagenter søger at genfortolke, omdefinere og omforme idéer, både hvad angår form og indhold. Perspektivet tillægger derved aktører (translationsagenter) en mere prominent rolle, end tidlige ny-institutionelle spredningsstudier (DiMaggio \& Powell 1983), og forsøger derigennem at overkomme kritikken gående på, at aktørers skabende sider undereksponeres i institutionelle analyser (Heugens, Pursey \& Lander 2009).

Som illustreret i Figur 1, knytter translation sig både til, hvordan organisationsidéer omsættes til praksis (kontekstualisering), og hvordan praksisser løsrives og omformes til abstrakte organisationsidéer eller koncepter (de-kontekstualisering) (Czarniawska \& Joerges 1996). Imidlertid er både tidlige bidrag (Czarniawska \& Joerges 1996), og senere bidrag (Sahlin \& Wedlin 2017; Lawrence 2017) til skandinavisk translationsforskning i langt ovevejende grad optaget af det første aspekt. Morris \& Lancaster (2006) viser fx, hvordan idéer om Lean Management blev omdannet fra en generel ramme til specifikke arbejdspraksisser i bygningsindustrien i Storbritannien. Kirkpatrick, Bullinger, Lega \& Dent (2013) demonstrerer, hvordan en generisk hospitalsstyringsmodel (JHH-modellen), fik væsensforskellige betydninger, i takt med at den blev implementeret på hospitaler i fire europæiske lande.

\footnotetext{
${ }^{2}$ Det skal anføres, at Rogers senere (fx Rogers 2003) benytter "re-invention" begrebet til at betone at innovationer kan ændres i takt med at de spredes, dog uden at det er blevet et fokusområde for Diffusion of Innovation litteraturen.
} 


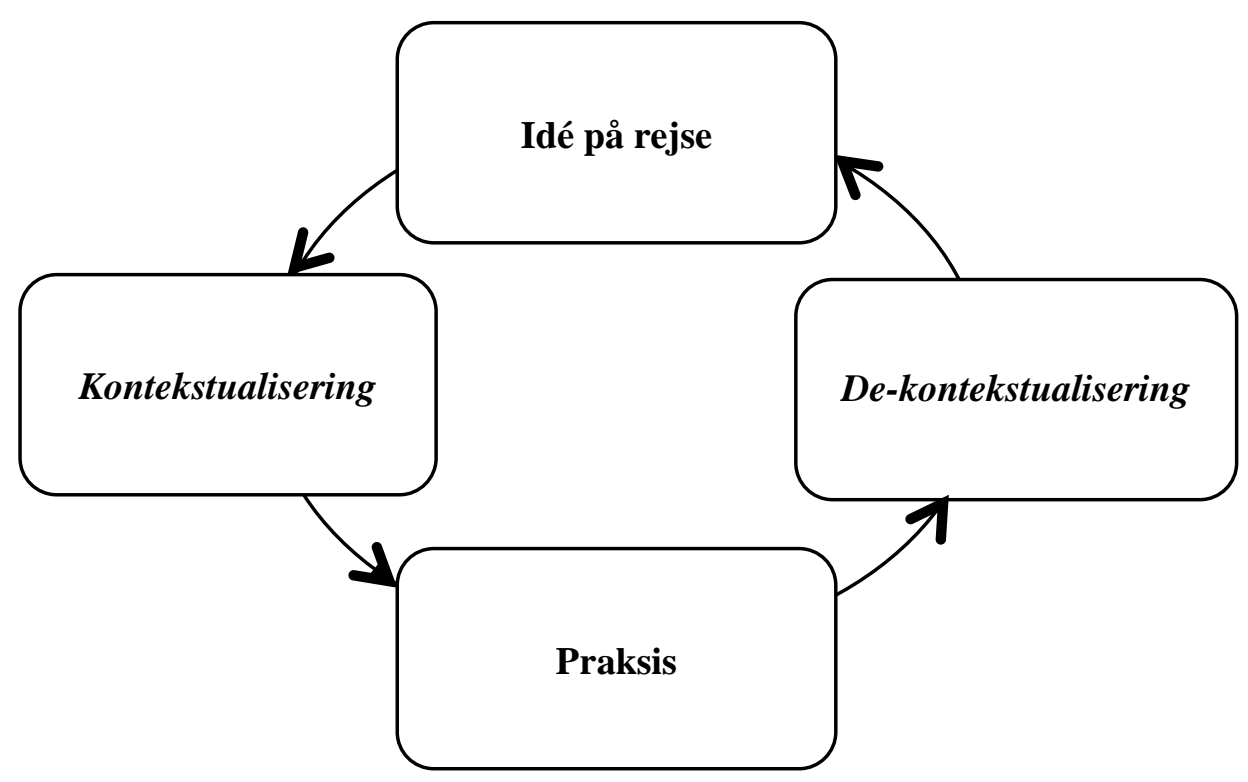

Figur 1: Translation af organisationsidéer

De-kontekstualiseringsaspektet har, som nævnt, fået mindre opmærksomhed i Skandinavisk translationsforskning. Røvik (2016) fremhæver, at den eksisterende litteratur er karakteriseret ved en "contextualization bias" (s. 292). Når omdrejningspunktet er de-kontekstualisering af organisatorisk praksisser, kan der sondres mellem "udhentning” og "udbringning” som strategi (Røvik 2007). ”Udhentning” henviser til, at de aktører, fx konsulenthuse eller interesseorganisationer, som søger at oversætte og overføre en bestemt praksis, befinder sig uden for den organisation, hvor praksissen er lokaliseret. "Udbringning” henviser derimod til, at aktører med erfaring med en bestemt praksis $i$ en bestemt organisation, formidler praksissen på arenaer uden for organisationen. Det er det sidste, som også er det mindst studerede fænomen (Røvik 2007), som er i centrum i denne artikel.

\section{Design og metode}

\section{Casen}

Til at belyse hvordan de-kontekstualiseringsprocesser forløber, bygger artiklen på et empirisk studie af "udbringningen" af en ny organisationspraksis, "mindset-baseret undervisning", i feltet af danske undervisningsinstitutioner. I Danmark fremstår mindset-baseret undervisning som en af tidens pædagogiske metoder med momentum, som flere og flere giver opmærksomhed (Nottingham 2013), navnlig i gymnasieskolen (Kortnum et al. 2016). Denne organisationspraksis 
er i sig selv inspireret af en global idé om "mindset", som navnlig den amerikanske psykologiprofessor og motivationsforsker Carol Dweck er eksponent for, gennem en række forskningsartikler (fx Blackwell, Trzesniewski \& Dweck, 2007) og bestseller-bøger (Dweck, 2006), om hvordan man opnår succes i uddannelsessystemet gennem motivering af elever i retning af et growth mindset. En grundpointe hos Dweck er, at måden elever tænker om sig selv og sine evner - samt den måde hvorpå de mødes af andre, fx forældre og undervisere, har afgørende betydning for, hvordan de klarer sig i skolen og uddannelse.

Dweck (2006) argumenterer for, at en elev enten kan have et overvejende fixed (fastlåst), eller et growth (udviklende) mindset (tankesæt), som får betydning for, hvordan eleven tilgår læring, og dermed hvor meget der rent faktisk læres. Et fixed mindset er udtryk for, at eleven anser sine evner for givne, og i store træk uforanderlige (fx "matematik er bare ikke mig"), hvorimod et growth mindset er udtryk for, at egne evner og færdigheder anses som noget, der udvikles over tid, og derfor i høj grad kan påvirkes og tilegnes. Carol Dwecks forskning om betydningen af hhv. et fixed og et growth mindset, og hvordan elevers mindset kan ændres, udgør ikke en færdigpakket undervisningsmetode, men snarere en række principper for undervisningspraksis, der kan stimulere et growth mindset, herunder selvrefleksion over eget mindset, feedback-former, sprogets betydning, indsatsens betydning og læring gennem fejl (Dweck 2006; Blackwell, Trzesniewski \& Dweck, 2007).

VG indtager en særlig interessant rolle i udviklingen og udbredelsen af mindset-baseret undervisning i Danmark. Gymnasiet har ikke alene omdannet Dwecks idéer til egne undervisningspraksisses (kontekstualisering), men har også været særdeles aktive i formidling og promovering af deres erfaringer i de omgivelser, der omslutter dem via sociale medier, seminarer, oplæg, konferencer mv. (de-kontekstualisering). Som illustration af VG's rolle som bannerfører for mindset-baseret undervisning, modtog underviserne på VG i 2014 Gymnasieskolernes Lærerforenings prestigefyldte uddannelsespris for deres mindset-projekt. Mindset-baseret undervisning præsenteres som et supplement til den tiltagende test-, karakter-og præstationsorientering i det danske uddannelsessystem (Kortnum et al. 2016).

VG blev etableret i 1973 og huser i dag 1050 elever, 100 undervisere og 20 teknisk-administrativt personale. Som det er sædvane blandt danske gymnasier har VG en flad organisationsstruktur med rektor, en gruppe uddannelsesledere (4) og en stor gruppe af lærere (+100). Selvom elevtal og 
undervisningsstab på VG fra 2008 til 2016 er fordoblet, står skolen i lokalområdet i skyggen af den større og bedre kendte Viborg Katedralskole. VG indtager ikke en elite position i feltet af danske undervisningsinstitutioner, hvorfra de kan "broadcaste" idéer, men repræsenterer snarere det typiske gymnasium, lokaliseret i Midtjylland.

Mindset-projektet på VG indskriver sig i rækken af flere undervisningsinitiativer, som i det seneste årti er blevet iværksat på gymnasiet. En udvikling, som ikke mindst er blevet fremmet af selvejet i 2007, hvor gymnasiernes økonomi blev afhængigt af taxametertilskud og derved antallet af elever. Som danske gymnasier er flest, er undervisningen på VG ikke bundet op på én bestemt pædagogisk metode, men der er store frihedsgrader for underviserne til at bestemme, hvilke pædagogiske metoder de benytter. Det er kort fortalt forhistorien til mindset-projektet på VG, som tager sin spæde start i sommeren 2012.

\section{Datamateriale}

I overensstemmelse med tidligere studier inden for skandinavisk translationsteori (fx Morris \& Lancester 2006), bygger nærværende undersøgelse på et longitudinelt, kvalitativt case studie, hvor mindset-projektet på VG er analyseret fra 2012 til 2016.

Det empiriske datamateriale, der anvendes i artiklen, bygger på en kombination af interviews og dokumenter. I april $2014 \mathrm{blev}$ der gennemført semi-strukturerede interviews med rektor, en uddannelsesleder og fem undervisere, der var involveret i arbejdet med at indføre mindset-baseret undervisning som pædagogisk metode. Disse data gjorde det muligt at belyse, hvordan mindsettilgangen blev forstået af ledere, hvordan de arbejdede med at oversætte Dwecks idéer til ny undervisningspraksis. Endvidere viste denne første runde af dataindsamling, hvordan to personer - en uddannelsesleder og en matematiklærer - var særligt indflydelsesrige i udformningen af mindset-projektet på VG, og særligt i at fremme idéen bredere i uddannelsessektoren.

Uddannelseslederen blev derfor interviewet igen i juni 2015, juni 2016 og december 2016, og matematiklæreren blev geninterviewet i juni 2015 og december 2016. Denne interviewrunde omfattede også interviews med VG's nye rektor, to uddannelsesledere og fem undervisere (februar 2017). Samlet set gav denne runde af interviews et værdifuldt indblik i mindset-projektets forløb og fremdrift, og det specifikke arbejde, der blev udført i kontekstualiseringen og dekontekstualiseringen af mindsetbaseret undervisning. 
Ud over interviewene består datamaterialet af en række officielle skriftlige dokumenter om mindset-projektet (se tabel 1). Dokumenterne blev indsamlet med udgangspunkt i VG's hjemmeside og blog, hvor mindset-projektet er grundigt beskrevet via indlæg fra uddannelsesledere og undervisere. Herudover har jeg fået adgang til power point præsentationer og prezi præsentationer om mindset-baseret undervisning, og til interne dokumenter, herunder evalueringer og logbøger fra elever, som har modtaget mindset-undervisning, samt intranetmateriale, hvor mindset-projektet er blevet diskuteret personalet imellem. Hermed sættes to undersøgelsesteknikker i spil (interviews og dokumentanalyse) - i en øvrigt ofte anvendt kombination (Lynggaard 2010).

\begin{tabular}{lll} 
Tabel 1: Oversigt over datamateriale & \\
Data & Antal & Original datakilde \\
\hline Interviews & 21 & Respondenter \\
Sociale media (Blog) & 22 indlæg $(32$ & Viborg Gymnasium og \\
& sider $)$ & HF \\
Intranet & 13 indlæg $(15$ & Viborg Gymnasium og \\
& sider $)$ & HF \\
Power point præsentationer & $8(130$ sider $)$ & Uddannelsesledere, \\
& & matematiklærer \\
Prezi præsentationer & $3(17$ sider $)$ & Uddannelsesleder \\
Projektplaner, nyhedsbreve & $21(93$ sider $)$ & Viborg Gymnasium og \\
mv & & HF \\
Studenterevaluering af & $2(25$ sider $)$ & Viborg Gymnasium og \\
mindset-projektet & & HF \\
Avisartikler & $10(22$ sider $)$ & Medier \\
\hline
\end{tabular}

Analysen er opbygget i tre forskellige, men sammenhængende faser, som knytter sig til mindsetbaseret undervisnings indrejse i feltet af danske undervisningsinstitutioner, med særlig fokus på VG's entreprenante rolle. 


\section{Analyse}

\section{Fase 1: En idé importeres - ny praksis udvikles}

Det var en nytiltrådt uddannelsesleder, som i 2012 begejstredes for idéen om at inddrage mindsettænkningen i undervisningen på VG. Han forklarer:

Jeg var oprindeligt inspireret af særlige sportsmiljøer, som var exceptionelle gode til at udvikle talenter. Kunne vi mon overføre dele af denne tænkning til undervisningssektoren og skabe bedre undervisningsmiljøer? Jeg begyndte at læse Carol Dwecks mindset-bog, og fandt det vældig interessant at afprøve hendes idéer på vores gymnasium.

I efteråret 2012 blev VG's mindset-projekt officielt igangsat inspireret af Carol Dwecks bøger og forskningsresultater. Det var fra starten frivilligt for undervisere, om de ville deltage i mindsetprojektet, og en 2.g-klasse blev udvalgt til forsøgsklasse, hvor 6-8 lærere deltog. Projektet blev præget af en pionerånd med ildsjæle blandt undervisere og ledere. I klasselokalerne begyndte undervisere i løbet af 2012 med at oversætte principperne fra Carol Dwecks mindset-forskning til "hands-on" undervisningsredskaber tilpasset dansk gymnasiekontekst. Såvel ledere som undervisere beretter om, hvordan det var en omfattende og vedvarende opgave at filtrere de mange amerikanske forskningsresultater til konkrete undervisningspraksisser, der kunne bruges i en dansk gymnasieklasse. Der blev udviklet en række nye undervisningspraksisser, fx et mindsetrefleksionsskema bestående af 12 spørgsmål til skolens elever, der afspejlede forskellene på et fixed og growth mindset, og som indikerede særlige fokusområder, der kan stimulere den enkeltes elev i retning af et growth mindset. Andre begyndte at arbejde med "det risikofrie klassemiljø med plads til fejl", og igen andre med "karakterfrie afleveringer". En underviser fortæller:

Mindset-projektet har inspireret mig til at arbejde med nye metoder, og jeg forsøger mig nu med karakterfrie afleveringer. Eleverne får mundtlig og skriftlig feedback, når de afleverer en opgave, men uden en karakter. Det er først til eksamen, det handler om at få en god karakter. Indtil da handler det mere om at eksperimentere med opgaveløsningen og blive god til at løse opgaverne.

Pilotprojektet blev evalueret af eleverne efter ca. seks måneder, og resultaterne var overvejende positive (Viborg Gymnasium, u.å). I kølvandet på evalueringen besluttede ledelsen på VG, at 
læringsmetoden skulle afprøves i større skala i skoleåret 2013/2014. Det var stadig frivilligt for undervisere, om de ville deltage, men flere undervisere tilsluttede sig mindset-projektet, og nye translationer af mindset-budskabet udmøntede sig i nye undervisningspraksisser.

\section{Fase 2: Løsrivning af lokal praksis - en ny idé promoveres i feltet}

Gymnasieledelsen begyndte allerede i slipstrømmen på de positive erfaringer fra pilotprojektet at se konturerne til et spændende initiativ, som kunne videreformidles til andre undervisningsinstitutioner og måske styrke gymnasiets omdømme i omgivelserne. I løbet af efteråret 2013 begyndte VG - anført af den tidligere omtalte uddannelsesleder - mere systematisk, at arbejde på at skabe en lokal identitet (Sevón 1996) om mindset-projektet. Der blev etableret facebookgrupper og VG dannede egen blog, hvor erfaringer med mindsetbaseret undervisning formidles til interesserede læsere (både internt og ekstern).

I takt med at mindset-baseret undervisning fik mere fodfæste internt, begyndte VG således at indtage en aktiv rolle i udbredelse af mindset-budskabet i deres omgivelser. Navnlig uddannelseslederen, som var initiativtager til mindset-projektet, og en matematiklærer begyndte at lægge ressourcer, tid og energi i at formidle erfaringer fra projektet. Uddannelseslederen fortæller, hvordan de eksterne aktiviteter startede i det små og havde en positiv indvirkning på projektet i egen organisation:

Vi startede i det små. Vi havde noget medieopmærksomhed på mindset-projektet i slutningen af 2013, og Peter [matematiklæreren] og jeg blev inviteret til at holde foredrag om vores projekt. Hurtigt fik vi en fornemmelse af, at dette kunne blive stort. Vores præsentationer fremkaldte stor begejstring, hvilket igen resulterede i nye præsentationer på andre skoler. Det gav os endnu mere optimisme og energi til at videreudvikle mindset-projektet i vores egen organisation.

Matematiklæreren tilføjer:

I starten brugte jeg meget tid på at tilpasse og bruge Carol Dwecks idéer i mine matematik- og fysiktimer. Det blev den underliggende filosofi, der guidede min undervisning. På et tidspunkt fik jeg mulighed for at besøge andre skoler og fortælle dem om mindset-baseret undervisning. Det var en kæmpe motivationsfaktor. 
Tiden fra medio $2013 \mathrm{og}$ fremefter er således kendetegnet ved, at VG's erfaringer med mindsetbaseret undervisning, fx i form af mindset refleksionsskemaer, karakterfri afleveringer og risikofrie læringsmiljøer, ikke forbliver $i$ organisationen, men også formidles udadtil igennem en række mere eller mindre forbundne, og mere eller mindre styrede processer. VG fremstår i stigende grad som aktivt skabende af forståelser og praksisser, der forbindes med mindset-baseret undervisning i det felt som omslutter dem.

VG indtræder mao. på "de-kontekstualiseringsarenaen” (Røvik, 2007) med et ønske om at forandre eksisterende undervisningspraksis, skabe en vision for mindset-baseret undervisning (som fx udtrykt på VG's blog) og motivere andre uddannelsesinstitutioner til at følge i VG's spor. Uddannelseslederen fortæller:

Vi var motiveret af at fortælle "den gode historie" om Viborg Gymnasie og HF, personlige interesser og ikke mindst ændre den dominerende præstationsdiskurs i uddannelsessektoren. For mig var det meget vigtigt, og jeg allokerede alle mulige ressourcer til mindset-projektet. Jeg læste Dwecks forskningsartikler, jeg skrev regelmæssigt om mindset på vores blog, holdt mange oplæg på andre skoler og brugte mange ressourcer til at opbygge et netværk både lokalt og nationalt. Vi begyndte også at afholde seminarer om mindset-baseret undervisning og havde mange besøgende, der var interesserede i vores projekt.

Hertil kommer, at VG's eget mindset-projekt selv blev påvirket af de erfaringer, der drives af andre aktører i den danske uddannelsessektor, fx via erfaringsudveksling på seminarer, inspiration fra andre gymnasier og folkeskoler. I det følgende beskrives to centrale aktiviteter, der knytter sig til "udbringningen" af idéer om mindsetbaseret undervisning.

Skabe en vision, som rekker ud over egen organisation. VG publicerede i forskellige formater deres vision for mindset-baseret undervisning. Dette antog en række forskellige former med sociale medier som en central platform. Erfaringer med mindsetbaseret undervisning blev distribueret via VG's blog og facebookside og kunne tilgås gratis af interesserede læsere. På bloggen fandtes der i perioden fra 2013 til 2016 oversigt over konkrete undervisningsredskaber, gennemgang af centrale forskningsstudier, der dannede grundlaget for mindset-baseret undervisning, samt en række links til You Tube klip, hvor Carol Dweck beretter om mindset-teori, og hvor sportscoach 
Rasmus Ankersen fortæller om talentudvikling i sportsverdenen baseret på mindset-principper. Det er gennemgående, at VG fremstiller mindsetbaseret undervisning, som en pædagogisk metode forankret i solide forskningsresultater (Viborg Gymnasium u. å. - b). Samtidig knyttes der "lokale identitet-markører" (Røvik 2007) til mindset-projektet, fx blev sætningen: "vil du se god ud, eller vil du blive bedre" ved mange lejligheder anvendt som et sloganlignende udsagn. Det kommer bl.a. til udtryk i samtlige 8 analyserede power point præsentationer udarbejdet af uddannelseslederen og matematiklæreren.

Motivering af andre gennem netvarksbygning. VG initierede og afholdt flere inspirationsseminarer, hvor interesserede kunne komme og høre om gymnasiets mindset-erfaringer. Første gang i 2013, og ad flere omgange de efterfølgende år. Disse seminarer indeholdt typisk oplæg fra elever og undervisere fra VG, fra forskere og andre undervisningsinstitutioner, som havde erfaring med mindset-baseret undervisning. Disse aktiviteter kan dels ses som en måde at motivere andre undervisningsinstitutioner på, dels som et netværks- og allianceskabende initiativ. Det hører også med, at ledere og undervisere på VG ved flere lejligheder, og i stigende grad, blev inviteret til at holde eksterne oplæg om erfaringerne fra mindset-projektet. VG var tilmed ophavsmænd til flere netværk om brug af mindset-baseret undervisning. I 2014 tog gymnasiet initiativ til opstart af et lokalt netværksprojekt, hvor VG og fem andre institutioner i Viborg Kommune (tre folkeskoler, en børnehave og en landbrugsskole) samarbejdede om udbredelse og brug af mindset-filosofi. VG tog også aktiv del i Det Nordiske Talentnetværk i samarbejde med bl.a. Mærsk Mc-Kinney Møller Videncenter i Sorø.

\section{Fase 3: At begå sig på to arenaer - en balancerende akt}

I skoleåret 2014/2015 udbredes mindset-projektet yderligere på VG. Gymnasieledelsen besluttede, at alle 1. g klasser skulle introduceres til mindset-baseret undervisning. I den forstand udviklede projektet sig fra et "må gerne" til et "skal" projekt. I takt med at mindset-projektet udbredes til at omfatte flere elever, flere klasser og dermed flere undervisere, begyndte der at opstå skepsis om projektet. Det viser en gennemgang af meningsudvekslinger i efteråret 2014 på gymnasiets intranet. Nogle undervisere fandt det uholdbart, at gymnasieundervisning knyttes tæt sammen med Rasmus Ankersens tænkning i talentudvikling i sportens verden. Andre ytrede bekymring om, at gymnasiet anvendte for mange ressourcer på mindset-projektet, navnlig i forhold til "branding" af projektet i omgivelserne. Der var også undervisere, som følte sig tvunget ind i et projekt, de mente indskrænkede deres metodefrihed i undervisningen. Omvendt hævdede 
fortalerne for mindset-projektet, at kritikken mestendels var forfejlet, og beroede på manglende indsigt i hvad mindset-baseret undervisning i en dansk variant gik ud på. En uddannelsesleder vurderede situationen således:

Fra 2014 og fremefter blev mindset-projektet mere besværligt i vores organisation. Vi havde et stigende antal meget entusiastiske lærere, men der var også skeptikere, der udtrykte deres utilfredshed med projektet.

Paradoksalt nok begyndte den interne skepsis (blandt visse undervisere) at vinde indpas samtidig med at VG "på den store scene" høstede mere anerkendelse for projektet, fx som vinder af årets undervisningspris i 2014. (Gymnasieskolernes Lærerforening, 2014). Samtidig fik mindsetprojektet i denne fase i flere omgange positiv omtale i avisartikler og fagblade, fx under overskrifter som: "Talent er overvurderet - det handler om hårdt arbejde" (Gymnasieskolen 2014) og "Institutionerne hopper med på revolutionen” (Viborg Stifts Folkeblad 2014). VG's mindsetprojektet blev også afdækket i prime time af DR Nyhederne, hvor udvalgte undervisere, elever og ledere fortalte om potentialer og styrker ved at arbejde ud fra mindset-principper. Der blev i det hele taget gjort en dyd ud af at formidle mindset-baseret undervisning i gymnasiets omgivelser. Der afholdtes påny inspirationsseminarer på VG, hvor kendte danske foredragsholdere som Rasmus Ankersen (forfatter og sportscoach) og Morten Albæk (forfatter og forretningsmand) var blandt oplægsholderne. Navnlig uddannelseslederen og matematiklæreren fortsatte med at holde oplæg på andre skoler og konferencer om erfaringerne fra mindset-projektet, og de var med til at skrive en bog om mindset-baseret undervisning (Kortnum et al. 2016). En matematiklærer fortæller:

I 2015 holdt jeg mere end 30 præsentationer om mindset-baseret undervisning på andre skoler, konferencer og uddannelsesprogrammer. I 2016 er det mere og mindre det samme. Og det fortsætter bare. Den største udfordring er at finde tiden.

Et stigende antal danske skoler, navnlig gymnasier, blev inspireret af VG og begyndte at indføre mindset-baseret undervisning. Der findes ikke eksakte tal, men uddannelseslederen vurderede at mere end 30 skoler og "mange individuelle undervisere", begyndte at benytte mindset-baseret undervisning i 2015 og 2016. 
Samtidig med at mindset-projektet på VG opnåede stigende legitimitet i omgivelser, og VG brugte flere ressourcer på at formidle mindset-budskaber udadtil, opstod der, som nævnt, internt på VG et mere konfliktpræget og fragmentarisk syn på mindset-baseret undervisning, i takt med at metoden blev mere omsiggribende og involverede flere undervisere. Mens der i forrige fase var synergi mellem kontektualiseringsarbejdet internt i organisationen, og dekontektualiseringsarbejdet i omgivelserne, er denne fase således mere dilemmafyldt. En underviser reflekterede over situationen:

Det var paradoksalt. Og mærkeligt. Vi modtog en vigtig uddannelsespris, men lærerne blev samtidig mere og mere splittede. Mindset-projektet blev alvorligt kritiseret i vores organisation, men samtidig hypet i vores omgivelser.

Selv om den obligatoriske tilgang til brug af mindset-baseret undervisning på VG allerede blev afskaffet igen i skoleåret 2015/2016 (og erstattet med frivillighed), fortsatte kritikken med at følge mindset-projektet internt i organisationen. Endvidere faldt ledelsesopbakningen til projektet fra $2015 \mathrm{og}$ frem, da uddannelseslederen, der var bannerfører for mindset-projektet, fik nyt job. Mindset-baseret undervisning var integreret i undervisningspraksis blandt en gruppe af lærere, men det var svært at fremme en mindset-baseret undervisningskultur i hele organisationen. Samlet set illustrerer denne fase, at "udbringningen" af en organisatorisk praksis ikke alene forudsætter ildsjæle og et omfattende translationsarbejde, men at det også kan være vanskeligt at sikre sammenhæng mellem de eksterne aktiviteter (ud i feltet) og interne aktiviteter (i organisation). Casen indikerer, at det er en balancerende akt at begå sig på to arenaer (hhv. organisation og felt), og at der ikke nødvendigvis er synergi mellem "de to verdener".

\section{E. Konkluderende diskussion}

Mens Skandinavisk translationsforskning primært har belyst, hvordan "idéer på rejse" indoptages $i$ organisationer (kontekstualisering), har denne artikel særligt koncentreret sig om, hvordan organisationsidéer transformeres fra praksiskonteksten og søges udbredt i et felt (dekontekstualisering). Samlet set viser analysen, hvordan en organisation (VG) løftede en global idé (mindset) ind i egen organisation, tilpassede idéen og lod den forme undervisningspraksis. Samtidig blev erfaringerne herfra formidlet gennem en række forskellige kanaler og netværk. Da VG trådte ind på på de-kontekstualiseringsarenaen, var det ikke som neutral aktør, men snarere som institutionel forandringsagent (eller institutionel entreprenør; Battilana, Leca \& Boxenbaum 
2009) der videreformidlede egne translationer, kreerede en vision for mindset-baseret undervisning, opbyggede netværk og søgte at motivere andre aktører til at følge i deres fodspor. Derigennem var VG - og navnlig en entreprenant duo bestående af en uddannelsesleder og en matematiklærer - bannerførere i at "udbringe" idéen fra praksiskonteksten og derigennem skabe grobund for forandringer i feltet af danske undervisningsinstitutioner.

Resultaterne peger dermed på, at en vigtig forudsætning, der muliggør de-kontekstualisering (her udbringning af idéer) knytter sig til det arbejde, der udføres af ildsjæle i organisationer, der påtager sig rollen som institutionelle forandringsagenter. Som casen viser, blev mindset-baseret undervisning navnlig båret frem af en gruppe ildsjæle, som skabte en vision, som rakte ud over egen organisation og motiverede andre i feltet via alliance- og netværksbygning. Herudover præsenterede ildsjælene mindset-baseret undervisning i et kommunikerbart budskab, med besnærende slogans, og var derigennem med til at "produktivere” (Røvik 2007) idéen som en forudsætning for dens udbredelse i feltet. Mens litteraturen navnlig viser, hvordan konsulenter, ledelsesguruer, business media og interesseorganisationer indgår i de-kontekstualiseringsarbejdet (Abrahamson, 1996; Røvik, 2002; Sahlin-Andersson \& Engwall, 2002; Madsen \& Slåtten, 2018), viser denne artikel, hvordan aktører med erfaring med en bestemt praksis $i$ en bestemt organisation oversætter idéer fra organisationskonteksten, så de kan udbredes i et felt.

Analysen er også en påmindelse om, at samtidig varetagelse af translationsarbejde i egen organisation (kontektualisering) og i feltet (de-kontekstualisering), kan være problemfyldt. Mens "dobbeltrollen" i visse perioder gav idéen om mindset-baseret undervisning øget momentum og fremdrift, både internt og eksternt (fase 2), var det problem- og dilemmafyldt i andre (fase 3). Paradoksalt nok viser studiet, at kritikken af mindset-baseret undervisning tog til i den organisation, hvor idéen oprindeligt blev udviklet, samtidig med at idéen i stigende omfang opnåede popularitet i feltet.

Undersøgelsens empiriske analyse, såvel som teoretiske ståsted understøtter udviklingstendensen inden for institutionel organisationsteori i retning af at forstå organisationers muligheder for at agere som noget, der rækker ud over evnen til - magtesløs - tilpasning af omverdenpres (Powell \& Colyvas 2008). Som det blev tydeliggjort i casen, var VG optaget af at oversætte og tilpasse Carol Dwecks mindset-teori til "hands-on" undervisningsmetoder, samtidig med at de udviste entreprenant adfærd udi at skabe forandringer i et felt. Det skal imidlertid ikke udlægges som 
fortællingen om en heroisk forandringsagent, der egenhændigt skabte institutionel forandring. Som illustreret var VG under indflydelse af en global idé, og de indgik i forskellige netværk og blev præget af andre aktører i feltet i takt med, at de søgte at udvikle en vision for mindset-baseret undervisning og motivere andre aktører. Dette peger i retning af, at forstå organisationsidéer på rejse som aktiviteter, der udfolder sig som gensidigt forbundne aktiviteter mellem feltet og enkeltorganisationer (Czarniawska \& Joerges 1996; Smets, Morris \& Greenwood 2012; Nielsen, Mathiassen \& Newell 2014).

I artiklens bestræbelse på at bringe Skandinavisk translationsforskning ad nye veje igennem et studie af "udbringningen af organisationsidéer", må det holdes for øje, at de empiriske resultater baserer sig på et single case studie med fokus på én organisation, forankret i feltet af danske uddannelsesinstitutioner. Kommende studier af, hvordan organisationsidéer løsrives fra en given praksiskontekst, opfordres derfor til at undersøge, om lignende mekanismer kan genfindes i andre felter og sektorer, og navnlig studere, hvordan kontekstualisering og de-kontekstualisering er forbundne aktiviteter, der påvirker hinanden i vekselvirkningslignende processer.

\section{Referencer}

Abrahamson, Eric (1996). Management Fashion. Academy of Management Review 21 (1): $254-285$. https://doi.org/10.5465/amr.1996.9602161572

Ansari, Shahzad, Fiss, Peer C., \& Zajac, Edward. J. (2010). Made to fit: How practices vary as they diffuse. Academy of Management Review, 35: 67-92.

Blackwell, Lisa S., Trzesniewski, Kali H. \& Dweck, Carol S. (2007). Implicit theories of intelligence predict achievement across an adolescent transition: A longitudinal study and an intervention. Child Development 78 (1): 246-263. https://doi.org/10.1111/j.1467-8624.2007.00995.x

Battilana, Julie, Leca, Bernard \& Boxenbaum, Eva (2009). How actors change institutions: Towards a theory of institutional entrepreneurship. Academy of Management Annals, 3(1): 65-107. https://doi.org/10.5465/19416520903053598

Boxenbaum, Eva \& Pedersen, Jesper Strandgaard (2009). Scandinavian institutionalism - a case of institutional work. I: Institutional Work, Actors, and Agency in Institutional Studies of Organizations Lawrence, T. B., Suddaby, R. \& Leca, B. (eds.) (pp. 178-204).

https://doi.org/10.1017/CBO9780511596605.007 
Nielsen / Skandinavisk translationsforskning

Czarniawska, Barbara. (2009). Emerging Institutions: Pyramids or Anthills? Organization Studies 30 (4): 423-441. https://doi.org/10.1177/0170840609102282

Czarniawska, Barbara \& Joerges Bernward (1996). Travels of Ideas. I: Translating Organizational Change, B. Czarniawska and G. Sevón (eds.), New York: Walter De Gruyter.

https://doi.org/10.1515/9783110879735

Czarniawska, Barbara \& Sevón, Guje (1996). Translating Organizational Change: Walter de Gruyter. https://doi.org/10.1515/9783110879735

Czarniawska, Barbara \& Sevón Guje (2005). Translation Is a Vehicle, Imitation its Motor, and Fashion Sits at the Wheel. I: Global Ideas: How Ideas, Objects and Practices Travel in the Global Economy, Czarniawska, B. \& Sevón, G. (eds.), Copenhagen: Liber and Copenhagen Business School Press.

DiMaggio, Paul J., \& Walther W. Powell (1983). The Iron Cage Revisited: Institutional Isomorphism and Collective Rationality in Organizational Fields. American Sociological Review 48 (2): 147-160. https://doi.org/10.2307/2095101

Dweck, Carol S. (2006). Mindset: The New Psychology of Success. Ballantine Books

Greenwood, Royston Oliver, Christine, Sahlin-Andersson, Kerstin \& Suddaby, Roy (2008). Introduction. In R. Greenwood, C. Oliver, K. Sahlin, \& R. Suddaby (Eds.), The SAGE handbook of organizational institutionalism (pp. 1-46). London: Sage.

Gymnasieskolernes Lærerforening (2014). GL's uddannelsespris 2014 til larerkollegiet på Viborg Gymnasium og HF. http://www.gl.org/uddannelse/udd.politik/uddannelsespris/Sider/GLsuddannelsespris-2014.aspx (link senest tjekket d. 17. oktober 2018).

Gymnasieskolen (2014). Talent er overvurderet - det handler om hårdt arbejde. Medlemsblad for Gymnasieskolernes Lærerforening. Artiklen er skrevet af Sisken Laugesen, og udgivet d. 3. april 2014.

Heugens, Pursey P. M. A. R., and Lander, Michel W. (2009). Structure! Agency! (And Other Quarrels): Meta-Analyzing Institutional Theories of Organization, Academy of Management Journal 52 (1): 61-85. https://doi.org/10.5465/amj.2009.36461835 
Kjellberg, Pia K., Ibsen, Rikke, Kjellberg Jacob (2011). Fra pleje og omsorg til rehabilitering. Erfaringer fra Fredericia Kommune. København, Dansk Sundhedsinstitut.

Kirkpatrick, I., Bullinger, B., Lega, F., \& Dent, M. (2013). The Translation of Hospital Management Models in European Health Systems: A Framework for Comparison. British Journal of Management, 24: 48-61. https://doi.org/10.1111/1467-8551.12030

Kortnum, Allan, Nielsen, Jeppe, A. \& Arnborg, Peter. (2016). Mindsetbaseret undervisning - Fra præstationskultur til læringskultur. Dansk Psykologisk Forlag.

Latour, Bruno (1986). The Powers of Association. I: Power, Action, and Belief: A New Sociology of Knowledge, J. Law (ed.), London: Routledge.

Lawrence, Tom B. (2017). High-Stakes Institutional Translation: Establishing North America's First Government-sanctioned Supervised Injection Site. Academy of Management Journal, 60 (5): 1771-1800. https://doi.org/10.5465/amj.2015.0714

Lynggaard, Kennet (2010). Dokumentanalyse. I: Kvalitative metoder - en grundbog. Brinkmann, S., \& Tanggard, L. (red.). Hans Reitzels Forlag.

Madsen, Dag Øivind \& Slåtten, Kåre (2018). HR-analyse som ledelseskonsept og ledelsesmote. Samfundslederskab i Skandinavien 33 (1): 42-66.

Meyer, John \& Rowan, Brian (1977). Institutionalized Organizations: Formal Structure as Myth and Ceremony. American Journal of Sociology, 83 (2): 340-363. https://doi.org/10.1086/226550

Morris, Timothy \& Lancaster, Zoë (2006). Translating Management Ideas. Organization Studies 27 (2): 207-233. https://doi.org/10.1177/0170840605057667

Nickelsen, Niels Christian \& Scheuer, John Damm (2009). Tilblivelsen af det ny nordiske køkken: Claus Meyer som institutionel entreprenør. Psyke \&̊ Logos 30: 695-713.

Nielsen, Jeppe Agger, Mathiassen, Lars \& Newell, Sue (2014). Theorization and Translation in Information Technology Institutionalization. Evidence from Danish Home Care. MIS Quarterly 38 (1) 65-86. https://doi.org/10.25300/MISQ/2014/38.1.08

Nottingham, James (2013). Nøglen til laring - hvordan opmuntrer og inspirerer du til optimal laring? Dafolo. 
Pedersen, Jesper Strandgaard \& Dobbin, Frank (1997). The Social Invention of Collective Actors: On the Rise of the Organisation. American Behavioral Scientist 40: 431-43.

https://doi.org/10.1177/0002764297040004006

Powell, Walter W., \& Colyvas, Jeannette A. (2008). Microfoundations of institutional theory. In R. Greenwood, C. Oliver, K. Sahlin-Andersson, \& R. Suddahy (Eds.), The Sage handbook of organizational institutionalism: 276- 298. London: Sage.

https://doi.org/10.4135/9781849200387.n11

Rogers, Everett M. (1962). Diffusion of Innovations, New York: Free Press.

Rogers, Everett M. (2003). Diffusion of Innovations (5rd ed.), New York: Free Press.

Røvik, Kjell Arne. (2002). The secrets of the winners: Management ideas that flow. In K. SahlinAndersson, \& L. Engwall (Eds.), The Expansion of Management Knowledge: Carriers, Ideas and Sources: Pp.113-144. Stanford: Stanford University Press

Røvik, Kjell Arne (2007). Trender og translasjoner: Ideer som former det 21. århundrets organisasjon. Oslo: The University Press.

Røvik, Kjell Arne (2016). Knowledge Transfer as Translation: Review and Elements of an Instrumental Theory. International Journal of Management Reviews, 18 (3); 290-310.

https://doi.org/10.1111/ijmr.12097

Sahlin-Andersson, Kerstin. (1996). Imitating by Editing Success: The Construction of Organizational Fields. I: Translating Organizational Change, B. Czarniawska, and G. Sevón (eds.), New York, Berlin: Walter de Gruyter, pp. 69-92. https://doi.org/10.1515/9783110879735.69

Sahlin, Kerstin \& Wedlin, Linda (2017). The imitation and translation of management ideas. I The SAGE Handbook of Organizational Institutionalism, edited by Greenwood R., Oliver C., Lawrence T. B., Meyer R.E., 102-127. Sage: London.

Smets, Michael, Morris, Tim \& Greenwood, Royston (2012). From practice to field: A multi-level model of practice-driven institutional change. Academy of Management Journal, 55(4): 877-904. https://doi.org/10.5465/amj.2010.0013

Stokholm, Frank \& Lindholm, Mikael R. (2013). Thyra Frank \& Plejehjemmet Lotte. Gyldendal.

Viborg Gymnasium (u.å. - a). Evaluering af mindset-projektet. Intern papir. 
Viborg Gymnasium (u. å. - b). https://vghfmindset.wordpress.com/. Link lukket ned primo 2018.

Viborg Stifts Folkeblad (2014). Institutionerne hopper med på revolutionen. Artikel skrevet af Simon Thinggaard Hjortkjær. og udgivet d. 4. september 2014.

Wæraas, Arild, \& Nielsen, Jeppe Agger (2016). Translation Theory "Translated”: Three Perspectives on Translation in Organizational Research. International Journal of Management Reviews, 18 (3): 236-270. https://doi.org/10.1111/ijmr.12092 